\title{
Contact Dermatitis Knowledge Level in Batik Workers of Desa Batik, Tanjung Bumi, Bangkalan, Madura
}

\author{
Cita Rosita Sigit Prakoeswa, Rahmadewi, Trisniartami Setyaningrum, Damayanti, \\ Hasnikmah Mappamasing, Sylvia Anggraeni, Menul Ayu Umborowati \\ Departement of Dermatology and Venereology, Faculty of Medicine Universitas Airlangga, Dr. \\ Soetomo General Academic Hospital, Surabaya - Indonesia
}

\begin{abstract}
Background: Batik has been declared as a humanitarian heritage for oral and non-cultural culture. The increasing demand for batik may have a negative impact as the industry utilizes chemical agents. Hazardous chemical exposure to the skin in the batik industry may result in a high risk of occupational contact dermatitis. This study was conducted to find out the social determinants of health. Purpose: This study aims to assess the level of knowledge of the batik workers before and after health education about occupational contact dermatitis. Methods: This was an observational interview study, and the data were collected using questionnaires. This study involved 30 batik workers. We assessed the level of knowledge before and after the health education about occupational contact dermatitis. Result: There were 4 (13.3\%) male participants and 26 (86.7\%) female participants. The mean score of the pre-test was $66.98 \pm 10.10$, and the post-test was $77.77 \pm 13.53(\mathrm{p}<0.05)$. Conclusion: The result showed a significant difference between batik workers' knowledge before and after health education about contact dermatitis.
\end{abstract}

Keywords: Occupational contact dermatitis, batik workers, health education, social determinants of health.

Correspondence: Cita Rosita Sigit Prakoeswa, Department of Dermatology and Venereology, Faculty of Medicine Universitas Airlangga / Dr. Soetomo General Academic Hospital, Surabaya - Indonesia, Prof. Dr. Moestopo No.47, Surabaya Indonesia, cita-rosita@fk.unair.ac.id.

\section{BACKGROUND}

Batik was declared as a humanitarian heritage for oral and non-cultural culture by United Nations Educational, Scientific, and Cultural Organizations (UNESCO) on October 2, 2009. In 2014, Yogyakarta was named as the world's batik city by the World Craft Council (WCC) because it fulfils the criteria for historical, cultural, and conservation values and generation transfer, economic value, environmental concern, an international reputation, and sustainable commitment values. Apart from Yogyakarta, many cities in Java Island are also famous for their batik crafts, such as Surakarta, Pekalongan, and Cirebon. ${ }^{1}$

Madurese batik originates from Madura island in East Java, and it is famous for its distinctive batik. It portrays coastal patterns in sharp and striking colors such as red, green, and blue. Paseseh Village in Madura island is a well-known regional center for batik craftsmanship. It also serves as a recreational area and, most importantly, a hub for batik sellers and buyers to transact for decades. Batik stores are located next to each other, and they can be easily accessed through the main road. This village is fairly dense, with 5,567 residents, and most of them work as batik workers. ${ }^{1,2}$

Synthetic dyes will further expose the workers to harmful pollutants such as heavy metals, suspended solids, or organic substances. Such exposure can harm the body through the skin and respiratory mucous. Kusbandono et al. in reported that irritant and allergic contact dermatitis were the most common causes of occupational diseases. Batik workers are almost constantly exposed to color dyes. Furthermore, exposure to dyes can disrupt the skin's physiological condition, making the skin more susceptible to skin diseases. ${ }^{1,3,4}$ This study was motivated by the occupational effect of the increased Indonesian batik demand, especially in Madura, which affects the batik workers' health. Exposure to hazardous chemicals to the skin may result in an increased incidence of occupational contact dermatitis. This study was conducted to find out the social determinants of health.

\section{METHODS}

This was an online observational interview study involving 30 batik workers. The data were collected using questionnaires. The inclusion criteria were batik workers aged 15-60 years and willing to participate in the study. The participants have filled pre-test questionnaires regarding occupational contact dermatitis, continued by online health education and distribution of educational media (leaflets and booklets) to the batik workers. The post-test 
questionnaire was given after the online health education session. This study had been approved by the ethics committee of Dr. Soetomo General Academic Hospital Surabaya (0098/KEPK/XI/2020).

\section{RESULT}

A total of 30 participants were included in the study, of whom $4(13.3 \%)$ were males, and $26(86.7 \%)$ were females. Batik workers aged 15-59 years are in the vulnerable population, with a mean age of $34.90 \pm$ 9.81. The mean of the pre-test and the post-test score was $66.98 \pm 10.10$ and $77.77 \pm 13.53$. The results showed a statistically significant difference between pre-test and post-test mean scores after the health education $(\mathrm{p}=0.000)$.

Table 1. Demographic data of batik workers

\begin{tabular}{lll}
\hline & \multicolumn{1}{c}{ Variable } & Result \\
\hline Sex & & \\
& Male, $n(\%)$ & $4(13.30 \%)$ \\
Female, $n(\%)$ & $26(86.70 \%)$ \\
\hline Age $($ mean \pm SD) & $34.90 \pm 9.81$ \\
\hline
\end{tabular}

SD: Standard deviation

Table 2. Pre-test and post-test knowledge

\begin{tabular}{ccc}
\hline Pre-test result $($ mean $\pm \mathrm{SD})$ & Post-test result $($ mean $\pm \mathrm{SD})$ & $p$-value* $^{*}$ \\
\hline $66.9877 \pm 10.10745$ & $77.7733 \pm 13.53236$ & 0.000 \\
\hline
\end{tabular}

*Wilcoxon test

SD: Standard deviation

\section{DISCUSSION}

Table 1 showed that most of the research participants were females $(26 ; 86.70 \%)$. Occupational skin disease (OSD) is the second most common cause of occupational disease. The most common skin disease among workers was contact dermatitis (9095\%). Epidemiological data in Indonesia showed 97\% of skin disease among workers were contact dermatitis, of which $66.3 \%$ were irritant contact dermatitis and $33.7 \%$ were allergic contact dermatitis. ${ }^{5,6,7}$ The international incidence of occupational contact dermatitis was estimated around 11-86 cases per 100.000 workers per year. A study in Australia reported contact dermatitis of 2.15 cases per 10.000 workers per year. Meanwhile, in Europe, it was reported a higher case of 5-19 per 10,000 workers. In the Germany, the incidence of contact dermatitis was 7 cases per 10,000 workers and 8 per 10,000 workers in Finland. $8,9,10$

The mean pre-test score was $66.98 \pm 10.10$, and the mean post-test score was $77.77 \pm 13.53$. Batik workers' knowledge has been improved significantly after the health education session about occupational contact dermatitis $(p<0.05)$. There have been $20 \%$ increase of total correct answer from $73 \%$ in pre-test to $93 \%$ in post-test questions about skin inflammation. The second and third questions were about the effect of harmful substances on the skin and the materials used in batik workers. The total correct answer for each questionnaire has increased from $83 \%$ to $93 \%$ and $67 \%$ to $87 \%$, respectively. The batik workers' knowledge of occupational dermatitis has improved after the health education. Another study reported that the knowledge level on the causes of contact dermatitis was $63.6 \%$ which was in the moderate category, and $62 \%$ for salon workers, placed them under the adequate category. ${ }^{11}$

Witasari et al. reported that the most common chief complaint in contact dermatitis was itching (84\%), followed by a burning sensation in the skin $(18 \%)$. Contact dermatitis has a variety of complaints. Most patients complain about a burning sensation accompanied by redness of the skin, vesicles, and blisters in the acute phase. In the chronic phase, most patients complain about dry skin and tight sensations on the skin. The lesions appear as lichens with cracks and fissures. ${ }^{12,13}$ Some of these complaints were also asked on the questionnaire, and the total correct answer has been increased by $11.75 \%$ ( $80 \%$ in pre-test score and $91.75 \%$ in post-test score). Hutagalung et al. reported the highest level of knowledge of respondents about the symptoms of contact dermatitis was $39.4 \%$, which was in the good category. ${ }^{11}$

Contact dermatitis can affect the workers' quality of life. Some disabilities that can interfere with the work are pain, itching, and psycho-social behavior. Occupational contact dermatitis may have an impact on work because of its physical and psycho-social effect. Sixty-six percent of contact dermatitis cases occurred on the hands. ${ }^{14}$ 
Workers can prevent contact dermatitis by substituting the causative substance with a less harmful material, reducing allergen exposure, and wearing personal protective equipment. Regular use of emollients helps maintain the functional integrity of healthy skin and may reduce the risk of contact dermatitis. ${ }^{15,16}$ Workers should be provided with training programs that educate about hazard they may be exposed and how to protect themselves. Worker's education and training program can help reduce the incidence of occupational contact dermatitis. ${ }^{17,18}$ Statement about how to prevent and overcome contact dermatitis had been included in the questionnaire. From the results obtained, there was an increase in correct answers.

In conclusion, the result showed a significant difference between batik workers' knowledge before and after the health education about contact dermatitis. There was a significant improvement in batik workers' knowledge about occupational contact dermatitis after the health education session. The health education session about occupational contact dermatitis was expected to decrease occupational contact dermatitis incidence among batik workers.

\section{Acknowledgment}

We thank Universitas Airlangga Surabaya and Batik Zulpha Madura for supporting this research.

\section{REFERENCES}

1. Tresnadi C, Sachari A. Identification of values of ornaments in Indonesian batik in visual content of nitiki game. J Arts Humanit 2015; 4(8): 25-39.

2. Helen I, Supriyapto Yahya L., Moeis X, Sumarsono H. Batik pesisir pusaka Indonesia : koleksi Hartono Sumarsono. Jakarta: Kepustakaan Populer Gramedia; 2011.

3. Ramos PR, Borges AS, Brasileiro A. Textile allergic contact dermatitis caused by occupational exposure-An overlooked condition. Contact Derm 2018; 79(5): 323-4.

4. Young E, Andersen KE, Bruze M, GiménezArnau A, Ross-Hansen K, Johansen JD, et al. Twenty-eight-day follow-up of patch test reactions to p-phenylenediamine and pphenylenediamine dihydrochloride: A multicentre study on behalf of the European Environmental and Contact Dermatitis Research Group. Contact Derm 2019; 81(1): 1-8.

5. Bepko J, Mansalis K, Grant D, Air T, Base F. Common occupational disorders: asthma, COPD, dermatitis, and musculoskeletal disorders. Am Fam Physician 2016; 93(12): 1000-6.

6. Diepgen TL. Occupational skin diseases. J Dtsch Dermatol Ges 2012; 10(5): 297-315.

7. Hudyono. Dermatitis kontak akibat kerja. $4^{\text {th }}$ ed. Indonesia: Raja Grafindo Persada; 2002. p. 70-3

8. Holguín-Gómez L, Sastre Domínguez J. Occupational contact dermatitis in Spain. J Investig Allergol Clin Immunol 2017; 27(2): 1346.

9. Lampel HP, Powell HB. Occupational and hand dermatitis: a practical approach. Clin Rev Allergy Immunol 2019; 56(1): 60-71.

10. Shakik S, Arrandale V, Holness DL, Macleod JS, Mcleod CB, Peter A, et al. Dermatitis among workers in Ontario : results from the occupational disease surveillance system. Occup Environ Med 2019; 76(9): 625-31.

11. Hutagalung AL, Hazlianda CP. Tingkat pengetahuan dan sikap pekerja binatu terhadap dermatitis kontak di kelurahan Padang bulan tahun 2017. MDVI 2019; 46(3): 122-6.

12. Witasari D, Sukanto H. Dermatitis kontak akibat kerja: penelitian retrospektif (occupational contact dermatitis: retrospective study). Berkala Ilmu Kesehatan Kulit dan Kelamin 2014; 26(3): 161-7.

13. Usatine RP, Riojas M. Diagnosis and management of contact dermatitis. Am Fam Physician 2010; 82(3): 249-55.

14. Kalboussi H, Kacem I, Aroui H, El Maalel O, Maoua M, Brahem A, et al. Impact of allergic contact dermatitis on the quality of life and work productivity. Dermatol Res Pract 2019: 1-6.

15. Al-otaibi ST. Prevention of Occupational Contact Dermatitis. J Ergonomics 2016; 6(3): 9-11.

16. Adisesh A, Robinson E, Nicholson PJ, Sen D, Wilkinson M, Robinson E. U.K. Standards of care for occupational contact dermatitis and occupational contact urticaria. $\mathrm{Br} \mathrm{J}$ Dermatol 2013; 168(6): 1167-75.

17. CDC. Skin Exposure \& Effects: Recommendation and Resources 2013. Available from:

https://www.cdc.gov/niosh/topics/skin/recomme ndations.html

18. Zack B, Arrandale VH, Holness DL. Preventing Occupational Skin Disease : A review of training programs. Am J Contact Dermatitis 2017; 28(3): 169-82. 